\title{
THE EFFECT OF LOW IMPACT AND MIXED IMPACT AEROBIC EXERCISES ON BODY FAT PERCENTAGE
}

\author{
Umar \\ umarmardesia@gmail.com \\ Sport Science Faculty Universitas Negeri Padang Padang, West Sumatera
}

\begin{abstract}
This study aimed to determine the effect of aerobic exercise and a low mixed impact on lowering body fat percentage. It is based on problems that are often found in someone who is having difficulties to lose excess weight (overweight). As is known, the excess weight is usually caused by excess body fat, causing obesity. The target population of this research is the student of FIK UNP, while the student population is affordable UNP forces FIK Coaching Education 2010/2011. Study sample as many as 20 people were taken by purposive sampling technique. The treatment given to group 1 low impact aerobic exercises, while group 2 mixed impact aerobic exercise for 16 times the exercise. The instruments used to determine to what body fat percentage is Calculator-Aneka-Fitnes. The results showed: 1. Low impact aerobic exercise can lower body fat percentage $\left(\mathrm{p}=0.005<\alpha=0.05\right.$ or $\left.\mathrm{t}_{\mathrm{hit}}=3.667>\mathrm{t}_{\mathrm{tab}}=2.26\right)$, 2. Mixed impact aerobic exercise can lower body fat percentage $\left(p=0.000<\alpha=0.05\right.$ or $\left.t_{\text {hit }}=7.423>t_{\text {tab }}=2.26\right)$, 3 . There is no difference between the effect of low impact aerobic exercises and the mixed impact of the decline in the percentage of body fat $\left(\mathrm{p}=0.526>\alpha=0.05\right.$ or $\mathrm{t}_{\text {hit }}=0.660<\mathrm{t}_{\mathrm{tab}}=$ 2.036).
\end{abstract}

Keywords; aerobics, low impact, mixed impact, body fat percentage

\section{Introduction}

Advancement of the science and technology today, from one side of a person is very helpful in a variety of daily activities effectively and efficiently, but from the other side, could unwittingly harm the health and fitness levels, this can cause the body to have the hypokinesia (lack of movement), because going everywhere only using transport, including when going to the top floor of a high rise building, enough to take the elevator. This condition can be aggravated if someone is always to consume high-calorie foods, which can cause imbalance of calories (calories that go much more than that incurred), and this can lead to obesity (overweight).

Obesity not only causes the body to over weight ( overweight), but more severe effects could lead to the emergence of a variety of degenerative diseases such as coronary heart disease, hypertension, diabetes mellitus and rheumatism. In addition, obesity is the body that would interfere with the appearance of a slow-moving, and beautiful to look at. Moore says that; " health problem caused or exacerbated by obesity are cardiovascular disorders, and respiration, such as hypertension, coronary heart disease, varicose veins".

To avoid obesity, a lot of things you can do such as regular physical exercise, consuming food as needed, avoid alcoholic beverages and adequate rest. This study aimed to examine the effect of physical exercise, especially aerobic exercise and low impact peresentase mixed impact on body fat reduction. 


\section{Theory Study}

\section{Body Fat Percentage}

Fats are organic compounds consisting of carbon atoms $(\mathrm{C})$. hydrogen $(\mathrm{H})$. and oxygen $(\mathrm{O})$. Fat that has a high melting point is solid at room temperature are called fat, while having a low melting point liquid called oil (Depkes, 2007). If hydrolyzed fats will produce one molecule of glycerol and three fatty acids .

Department of Health (2007) have indicated that, terdir of fatty acids :

a) unsaturated fatty acids ( vegetable oils), vegetable fat contained in sesame oil, corn oil, olive oil, peanut oil, vegetable oil, while the fruits abundant in avocados, bananas.

b) saturated fatty acids (animal fat), animal fats contained in egg yolks, beef, mutton, milk, butter and coconut oil are also present in. Consume high animal fat increase blood cholesterol has a tendency to cause coronary heart disease.

Fat tissue consists of fat cells increase in number during childhood are influenced by environmental factors such as diet and exercise habits. However the after puberty the number of fat cells remains stable. If there is excess carbohydrate in the diet or from the fat needed by the body, then these materials will not continue to burn, but this excess is converted by the body into fat and stored as a backup power at any time to be taken when needed by the body. The fat reserves will primarily stored under the skin, around your muscles, heart, lungs, kidneys and other organs .

Thickness of body fat defined as the presence of fatty tissue under the skin folds, but no one is in the blood called cholesterol. Body fat expressed as a percentage (\%) of the value of total body weight. Body fat percentage can be measured indirectly through the measurement of skin fold thickness in different parts of the body using the tools Caliper Skin Fold " Depdiknas (2000).

For more details, body fat percentage categories can be seen in the table below :

Table 1. Norm Body Fat Percentage

\begin{tabular}{|l|c|c|}
\hline \multicolumn{1}{|c|}{ Level } & $\begin{array}{c}\text { Male } \\
(\mathbf{\%})\end{array}$ & $\begin{array}{c}\text { Female } \\
(\mathbf{\%})\end{array}$ \\
\hline Athletic & $6-10$ & $10-15$ \\
\hline Good & $11-14$ & $16-19$ \\
\hline Acceptable & $15-18$ & $20-25$ \\
\hline Overweight & $19-24$ & $26-29$ \\
\hline Obesitas & 25 or more & 30 or more \\
\hline
\end{tabular}

Source; William (2002) in Wita Rizki Amelia, FKM UI 2009

The following image is a type of body fat percentage based on the number and BMI 


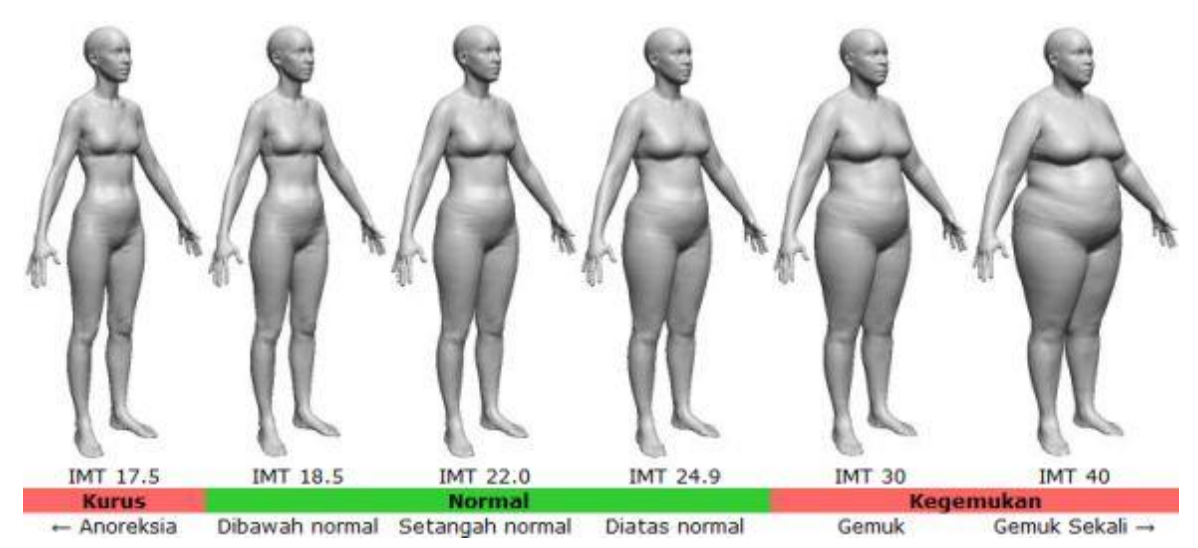

Figur 1. Type of body fat percentage based on the number and BMI Sumber; http://www.scientificpsychic.com/fitness/diet-kalkulator-id.html

\section{Obesity}

\section{a. The Meaning of Obesity}

Obesity or called the problem of overweight is not a new thing in Indonesian society. "It is well known, obesity is a factor in the state of degenerative diseases such as hypertension ( high blood pressure ), diabetes mellitus and coronary heart disease"

(Septiyadi, 2004).

\section{b . Causes of Obesity}

Obesity is caused by some of these following things ;

1) Caused by excessive food

In this case, the amount of food eaten each day, far away from the needs of the body's physiology. Snacking, is not how small. But, if it is done continuously as a habit, it can be a cause of excess calories which ultimately makes obesity.

2) Caused by lack of exercise factor

Lack of regular exercise also can be the cause of obesity, physical activity done very rarely, so that it can lead to lack of movement ( hypokinesia ).

3) Caused by the psychological factors

Emotional disturbance because of psychological stress or perceived environmental community life is not profitable, it can change a person's personality, so that the person making the food as his flight formation.

4) Talent fat

Obesity factors may influence the occurrence of obesity. The Actual influence is not clear yet, but there is evidence to support the fact that offspring obesity is a factor of the amplifier occurs. Sumanto (2009) says, " The person who was born with a talent obese if one of both parents is fat, the kid has $40 \%$ likely to be fat, if both parents are fats, chances of becoming fat increased two -fold to $80 \%$ ". 


\section{5) Enzymes}

Someone has a hereditary factor that tends to build up more body fat than others. This congenital metabolic properties indicate the presence of genes code for enzymes in the innate as adipose tissue lipoprotein lipase is more activ.

6) Hormones

In women who are experiencing menopause may decrease thyroid hormone function. The ability to use energy will be reduced by decreasing the function of this hormone. This is evident by the decrease in the body's metabolism, resulting in weight gain.

7) Metabolism

Basal metabolic rate of each person is not the same. There are people who have a higher basal metabolism, but there is also low. People who have a low metabolic rate tends to be heavier than people who have a fast metabolism due to low metabolism, energy consumption, and slower to be broken down into glycogen so that more fat stored in the body.

8) The effect of drugs

If someone is sick then the various drugs can be given with the intent to cure. There are several medications that can stimulate the "hunger center" so that the patient will increase his appetite. In a state of healing is long enough, the use of this drug will cause obesity. In addition, birth control pills can also cause weight gain gradually in women who used it.

\section{Aerobic Exercise}

\section{a. The Definition of Exercise}

Exercise is a physical activity that should be done to improve the physical ability, technique, tactics / strategy and mental. How is physical exercise will be carried out, depending on the objectives to be achieved. To reach the intended destination, the training program should be structured as it's rules.

b. Aerobic Gymnastics

Aerobic exercise is exercise that is done to the accompaniment of music. Movement in aerobic exercises adapted to the rhythm of the music. Meanwhile, according to Jackie Sorensens ( United States ):

"Aerobics gymnastics or physical fitness is a complete program of physical fitness, including exercise and excitement to express all the feelings by laughing, jumping, kicking, jogging, stretching, swaying with the movement of dance or movement combines traditional dance, folk dance, contemporary dance".

Furthermore Mulyono says that;

The Pioneer of aerobics is Dr. Kenneth Cooper in 1960 that the concept of musical rhythm and regular movement, so that the body can pump oxygen and heart rate increases. Aerobic exercise is any activity or exercise that demands more oxygen to extend the time and force the body to repair the system. 
Judging from the other forms of movement and rhythm of the music, aerobics consist of some sort such as: 1) low impact aerobics (buffeting mild), 2) Gymnastics high-impact aerobics (buffeting hard), 3) Gymnastics mixed impact aerobics (a mixture of low and high impact), 4) dangdut aerobics, 5) Disco Aerobics, 6) Sport aerobics and 7) Punky aerobics.

Furthermore, according to Mulyono that the benefits of aerobic exercise are as follows ;

To improve the durability of the heart and lungs and burn excess fat in the body due to motion activity to strengthen and build muscle and other body parts, such as waist, thighs, hips, abdomen and others.

\section{Methods}

\section{Types of Research}

This is a type of quasi-experimental research, by providing treatment in the form of low impact aerobic exercise and a mixed impact as the independent variable, while the percentage of body fat as the dependent variable.

2. Population and Sample

Target population in this study was a student from FIK UNP, while the affordable student population is Force Coaching Education Programs 2010/2011. Samples were taken about 20 people with pusposive sampling technique.

3. Operational definitions of variables

a. Gymnastics and Mixed Low Impact Aerobics

Aerobic exercise is a low impact exercise movement that accompanied the beat lightly with slow music, while mixed impact aerobics is aerobics mixed with low impact aerobics and high-impact and musical accompaniment with a mixture of slow and fast music.

\section{b. Body Fat Percentage}

Body fat percentage is the thickness of the fat tissue under the skin folds, where if someone has excess energy derived from fat, the excess will be stored under the skin in the form of body fat. To determine the percentage of body fat was used instruments Calculator - Assorted - fitness .

\section{c. Provision of Treatment}

The treatments were low impact aerobic exercises for group 1, and the mixed impact aerobic exercises for group 2. Each group was given treatment in accordance with the training program for 16 times the exercise, the exercise 3 times per week. Before the exercise, first performed preliminary tests ( pretest ), after completing the training program was again the second test ( posttest) the percentage of body fat.

\section{d. Research Instruments}

The instrument used to measure body fat percentage is the Calculator- Aneka-Fitness. The measurement results confirmed the body fat percentage tables. 
High:

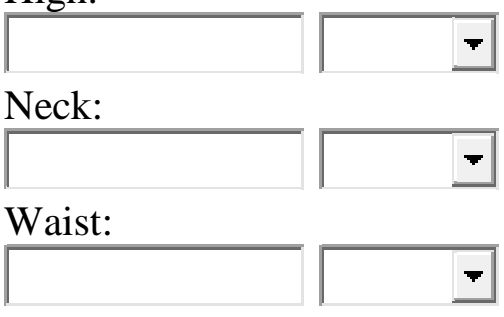

Hip (female):

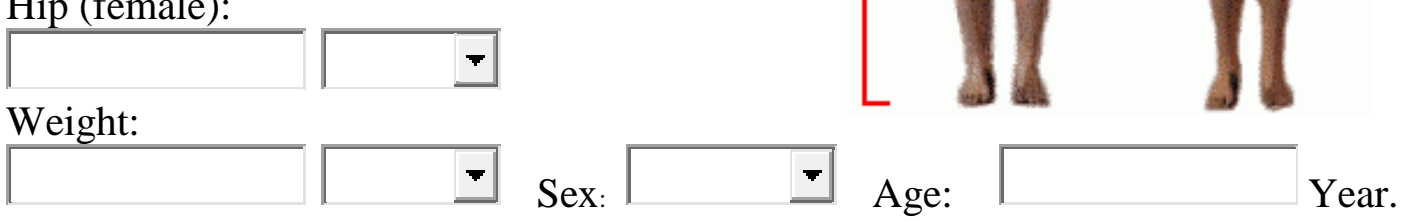

Activity:

Kurang (tidak atau sedikit berolahraga)

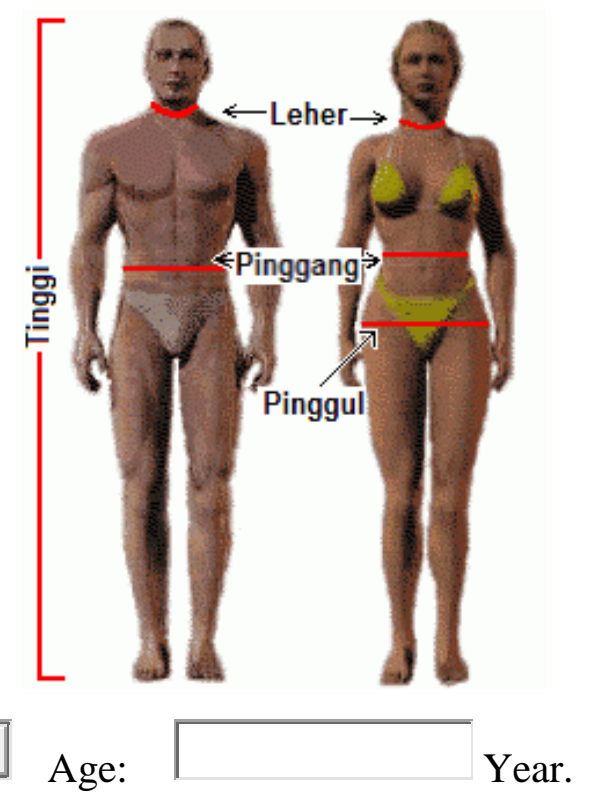

BMI :

Body Fat Percentage: $\ldots \%$

BMR:

Minimum calorie requirements:

Tabel 2. Body Fat Percentage

\begin{tabular}{|c|c|l|}
\hline \multicolumn{2}{|c|}{ Fat Percentage: } & \multirow{2}{*}{ Status } \\
\hline Female & Male & \\
\hline $10-12$ & $2-4$ & essential fatty \\
\hline $14-20$ & $6-13$ & athlete \\
\hline $21-24$ & $14-17$ & Fitness \\
\hline $25-31$ & $18-25$ & acceptable \\
\hline $32 \%$ more & $26 \%$ more & Obesity \\
\hline
\end{tabular}

The are some datas collected and to be analyzed with Calculator - Assorted - Fitness are: Height, weight, age, gender, neck circumference, waist circumference and hip circumference.

\section{e. Data analysis}

The Data obtained from measurements of body fat percentage, were analyzed by t-test inferential statistics. 


\section{Results}

Based on the analysis of data it can be concluded that;

1. There is an effect of low impact aerobic exercise significantly to the percentage of body fat $\left(\mathrm{p}=0.005<\alpha=0.05\right.$ or $\left.\mathrm{t}_{\text {hit }}=3.667>\mathrm{t}_{\mathrm{tab}}=2.26\right)$,

\begin{tabular}{|c|c|c|c|c|c|c|c|c|c|}
\hline \multicolumn{10}{|c|}{ Paired Samples Test } \\
\hline & & \multicolumn{5}{|c|}{ Paired Differences } & \multirow[b]{3}{*}{$\mathrm{t}$} & \multirow[b]{3}{*}{$\mathrm{df}$} & \multirow[b]{3}{*}{ Sig. (2-tailed) } \\
\hline & & \multirow[b]{2}{*}{ Mean } & \multirow{2}{*}{$\begin{array}{c}\text { Std. } \\
\text { Deviation }\end{array}$} & \multirow{2}{*}{$\begin{array}{l}\text { Std. } \\
\text { Error } \\
\text { Mean }\end{array}$} & \multicolumn{2}{|c|}{$\begin{array}{l}95 \% \text { Confidence Interval } \\
\text { of the Difference }\end{array}$} & & & \\
\hline & & & & & Lower & Upper & & & \\
\hline Pair 1 & $\begin{array}{l}\text { Pretest Low Impact - } \\
\text { Posttest Low Impact }\end{array}$ & 1.3700 & 1.1814 & .3736 & .5249 & 2.2151 & 3.667 & 9 & .005 \\
\hline
\end{tabular}

2. There is an effect of a significant mixed impact aerobic exercise to the percentage of body fat $\left(\mathrm{p}=0.000<\alpha=0.05\right.$ or $\left.\mathrm{t}_{\text {hit }}=7.423>\mathrm{t}_{\mathrm{tab}}=2.26\right)$,

Paired Samples Test

\begin{tabular}{|c|c|c|c|c|c|c|c|c|c|}
\hline & & \multicolumn{5}{|c|}{ Paired Differences } & \multirow[b]{3}{*}{$\mathrm{t}$} & \multirow[b]{3}{*}{$\mathrm{df}$} & \multirow[b]{3}{*}{ Sig. (2-tailed) } \\
\hline & & \multirow[b]{2}{*}{ Mean } & \multirow{2}{*}{$\begin{array}{c}\text { Std. } \\
\text { Deviation }\end{array}$} & \multirow{2}{*}{$\begin{array}{l}\text { Std. } \\
\text { Error } \\
\text { Mean }\end{array}$} & \multicolumn{2}{|c|}{$\begin{array}{c}95 \% \text { Confidence Interval } \\
\text { of the Difference }\end{array}$} & & & \\
\hline & & & & & Lower & Upper & & & \\
\hline Pair 1 & $\begin{array}{l}\text { Pretest Mixed Impact - } \\
\text { Posttest Mixed Impact }\end{array}$ & 1.7000 & .7242 & .2290 & 1.1819 & 2.2181 & 7.423 & 9 & .000 \\
\hline
\end{tabular}

3. There is no significant difference between low impact aerobics exercise and mixed impact on the percentage of body fat $\left(\mathrm{p}=0.526>\alpha=0.05\right.$ or $\left.\mathrm{t}_{\text {hit }}=0.660<\mathrm{t}_{\mathrm{tab}}=2.036\right)$.

Paired Samples Test

\begin{tabular}{|c|c|c|c|c|c|c|c|c|c|}
\hline & & \multicolumn{5}{|c|}{ Paired Differences } & \multirow[b]{3}{*}{$\mathrm{t}$} & \multirow[b]{3}{*}{ df } & \multirow[b]{3}{*}{ Sig. (2-tailed) } \\
\hline & & \multirow[b]{2}{*}{ Mean } & \multirow{2}{*}{$\begin{array}{c}\text { Std. } \\
\text { Deviation }\end{array}$} & \multirow{2}{*}{$\begin{array}{l}\text { Std. } \\
\text { Error } \\
\text { Mean }\end{array}$} & \multicolumn{2}{|c|}{$\begin{array}{l}95 \% \text { Confidence Interval } \\
\text { of the Difference }\end{array}$} & & & \\
\hline & & & & & Lower & Upper & & & \\
\hline Pair 1 & $\begin{array}{l}\text { Posttest Low Impact - } \\
\text { Posttest Mixed Impact }\end{array}$ & .4100 & 1.9644 & .6212 & -.9952 & 1.8152 & .660 & 9 & .526 \\
\hline
\end{tabular}

\section{Discussion}

Based on the analysis of the data, it turns out that the first hypothesis is accepted, thst there is an influence of low impact aerobic exercises to decrease body fat percentage. This is probably caused by the intensity of exercise at low impact aerobic system of energy is more dominant, so influential enough to burn fat in the body. In addition, the athletes (sample) who 
exercise were also given a list of menus that must be consumed during running exercise program. So it is with mixed impact aerobic exercise, with a combination of exercise intensity between low and high, can also cause maximum fat burning. Meanwhile, for the third hypothesis which states there is a difference in low impact aerobic exercise and a high impact on the percentage of body fat was rejected. Rejection of the third hypothesis is probably due to the amount of exercise performed by the sample is not enough to cause a difference.

\section{Conclusion}

Based on the analysis of data obtained;

1. There is an effect of low impact aerobic exercise significantly to the percentage of body fat $\left(\mathrm{p}=0.005<\alpha=0.05\right.$ or $\left.\mathrm{t}_{\mathrm{hit}}=3.667>\mathrm{t}_{\mathrm{tab}}=2.26\right)$,

2. There is an effect of a significant mixed impact aerobic exercise to the percentage of body fat $\left(\mathrm{p}=0.000<\alpha=0.05\right.$ or $\left.\mathrm{t}_{\text {hit }}=7.423>\mathrm{t}_{\mathrm{tab}}=2.26\right)$,

3. There is no significant difference between low impact aerobics exercise and mixed impact on the percentage of body fat $\left(\mathrm{p}=0.526>\alpha=0.05\right.$ or $\left.\mathrm{t}_{\mathrm{hit}}=0.660<\mathrm{t}_{\mathrm{tab}}=2.036\right)$.

So, it can be concluded that: to lower body fat percentage, both forms of aerobic exercise (low and mixed impact) can be used, and must be accompanied by consuming meals according to the list of menus that have been previously designed.

\section{Reference}

Depdiknas. Pedoman dan Modul Pelatihan Kesehatan Olahraga. Jakarta: Pusat Pengembangan Kualitas Jasmani, 2000

Depkes. Gizi dan Kesehatan Masyarakat. Jakarta: Raja Grafindo Persada, 2007.

Mulyono.,http://central-education.blogspot.com/2011/10/pengertian-dan manfaat-senam aerobik.html, (diakses 14 Februari 2011).

Septiyadi, Egy. Terapi Obesitas dengan Diet. Jakarta: Restu Agung, 2004.

Sorensens Jackie. http://ws-or.blogspot.com/2011/04/takaran-dan-latihan-senam-aerobik.html. (diakses 12 Januari 2011)

Sumanto, Agus. Tetap Langsing dan Sehat Dengan Terapi Diet. Jakarta: PT. Argomsedia pustaka, 2009.

http://anekafitness.com/kalkulator-aneka-fitness.htm (diakses 27 Agustus 2013)

http://www.scientificpsychic.com/fitness/diet-kalkulator-id.html (diakses 25 Agustus 2013) 